\title{
Lessons Learned from Organizational Crisis: Business Ethics and Corporate Communication
}

\author{
Shuhui Sophy Cheng ${ }^{1} \&$ Matthew W. Seeger ${ }^{2}$ \\ ${ }^{1}$ Department of Communication Arts, Chaoyang University of Technology, Taichung, Taiwan \\ ${ }^{2}$ Department of Communication, Wayne State University, Detroit, USA \\ Correspondence: Shuhui Sophy Cheng, Department of Communication Arts, Chaoyang University of \\ Technology, 168 Jifeng E. Rd., Wufeng District, Taichung 41349, Taiwan. Tel: 886-4-2332-3000. E-mail: \\ sophy@cyut.edu.tw
}

Received: March 18, 2012 Accepted: April 19, 2012 Online Published: June 16, 2012

doi:10.5539/ijbm.v7n12p74

URL: http://dx.doi.org/ijbm.v7n12p74

\begin{abstract}
This article examines the collapse of $\mathrm{HIH}$, the largest corporate failure in Australian business history. The company grew very quickly and did not have appropriate operational protocols in place to support the business expansion. Lies and deception within HIH hurt corporate profitability, accountability and image. The HIH debacle is a story of a company that showed little concerns for its stakeholders. In this case study, communication strategies are explored to understand how $\mathrm{HIH}$ executives managed their corporate communication when the company was under siege. The results of the study indicate that denial and shifting the blame to others within the company were the prototypical strategies used, especially as $\mathrm{HIH}$ corporate executives tried to distance themselves from the wrongdoings. HIH executives were more concerned about avoiding legal liabilities rather than attending to issues of public opinion. This study also illustrates the close connection between ethics, organizational crisis and open communication.
\end{abstract}

Keywords: organizational crisis, crisis response, communication responsibilities, business ethics

\section{Introduction}

The HIH (CE Heath International Holdings) Insurance debacle was Australia's largest corporate failure. HIH collapsed on March 15, 2001, and moved from provisional liquidation to full liquidation on August 27, 2001. Before its collapse, the HIH Group was the second-largest general insurer in Australia, comprised of 217 subsidiaries. HIH liquidators estimated that the company loss with debts was about A $\$ 5.3$ billion. The business ceased operation less than a year after the media first reported concern for the company's future. Its share price fell steadily from more than $A \$ 1$ in August, 2000 to its final price of $A \$ 0.175$ on February 27, 2001. The collapse directly affected stakeholders who wanted protection from unforeseen calamities but instead were left with worthless insurance. The impact of the HIH collapse has had far-reaching consequences since then.

Following the failure of the HIH group, the Australian government established the HIH Royal Commission to inquire into the causes of the collapse on May 21, 2001. According to the report of the HIH Royal Commission (2003), the primary reasons for the failure were inadequate provisions for insurance claims and improper pricing of past claims on the policies. This meant that HIH had mismanaged its core business services. Many of HIH's difficulties could be attributed to its failed acquisition strategy and business operation. Moreover, executive self-indulgence and corporate expenditure also hurt HIH. This corporate disaster raised the concerns of risk management within the company and corporate governance in Australia well before the Enron scandal in the U.S.

To date, several HIH directors have been prosecuted for numerous offenses. The HIH executives, whose unethical and illegal behavior violated the law, created the organizational crisis. It is important to understand how corporate executives responded to their wrongdoings especially since the strategies they used to address their corporate disasters drew widespread public criticism. To be more precise, this article seeks to explore how HIH executives managed their corporate communication when the company was under siege. For the purpose of this study, the analysis of this case focuses on the unethical actions, behavior and response of two HIH key protagonists; namely, founder and former Chief Executive Officer (CEO), Ray Williams, and non-executive director, Rodney Adler, because of "the distinctive way in which their identities are constructed in the corpus of 
HIH texts as corporate crooks" (Duarte, McAllister, \& Gray, 2005, p. 12).

Senge (1990) indicates that organizations must continually learn and adapt to their changing environments. In particular, corporate crises are those that are recognized as having important lessons for the organization. The aim of this study also tries to deliberate what lessons can be learned from the collapse of HIH. We would hope that corporate executives learn from this case study so that the organization can handle crises more appropriately in the future.

\section{Literature Review}

Pearson (1989) elaborates that "business ethics can be studied as a series of questions about how a business organization communicates with the individuals, groups, and other organizations with which it has relationships" (p. 111). Most often, business ethics is a question of communication ethics, and thus corporation communication plays the major role in managing the moral dimension of organizational conduct. Van Riel (1995) defines corporate communication as "an instrument of management by means of which all consciously used forms of internal and external communication are harmonized as effectively and efficiently as possible, so as to create a favorable basis for relationships with groups upon which the company is dependent" (p. 26). Furthermore, Grunig (2001) indicates that responsiveness is consistent with both the two-way symmetrical views of corporate communication and the stakeholder model of organizational ethics.

Recently crisis communication is a rapidly growing field in corporate communication practice. Organizations are inevitably facing crisis. Following accusations of wrongdoing, organizations usually engage in defense dialogue and image repair. Benoit (1995) has developed a comprehensive typology of strategies that include: denial, evasion of responsibility, reduction of the offensiveness of the act, corrective action, and mortification. Denial is the strategy employed when the rhetor simply chooses to deny the actions he is being accused of or shift the blame from the organization to outside individuals or agencies. Evasion of responsibility is the strategy that the rhetor can blame circumstances beyond his control. The third major image restoration strategy occurs when the rhetor attempts to reduce the degree of offensiveness experienced by the accuser. The fourth strategy is corrective action, which attempts to correct the situation rather than counterbalance it. The final image restoration strategy, mortification, requires the rhetor to take responsibility for the action and to issue an apology. The assumption underlying Benoit's strategies is to maintain or preserve one's image or reputation after alleged or suspected wrongdoing. This process of image management is also known as "face-work."

Benoit's image repair theory has been tested by himself and other researchers to present how they have been used by various organizations in different situations. For example, Benoit and Brinson (1994) investigated AT\&T's defense following a breakdown of its long-distance service in New York in September, 1991. Initially, AT\& T tried to shift the blame to low-level workers. As the complete story emerged, AT\&T promised corrective action and bolstered its image by stressing its commitment to service excellence. Based on image restoration strategies, Thomsen and Rawson (1998) analyzed Odwalla's response to an e. coli poisoning crisis in October, 1996. They found Odwalla effectively employed corrective action, compensation, defeasibility, bolstering, and, in the final stages of the crisis, transcendence. Odwalla's prompt actions combined with its goodwill that enabled it to resolve the crisis and reinvent its image.

Coombs (2007a) also offers a list of 10 common crisis communication strategies. These 10 strategies have been grouped into four postures: denial, diminishment, rebuilding, and bolstering. The denial posture includes attacking the accuser, denial, and scapegoating strategies. The denial strategies attempt to deny responsibility for an event and shift the blame from the organization to others. Managers deny the truth of the rumor or refute the charges of immoral conduct. The diminishment posture includes excusing and justifying strategies. The diminishment strategies seek to reduce the attributions of organizational control for the crisis or the negative impact of the crisis. Managers try to introduce solid evidence to lessen an organization's connection to the crisis. The rebuilding posture includes compensation and full apology. The rebuilding strategies try to improve the organization's reputation by offering material and/or symbolic forms of aid to victims. Basically, the managers say and do things to benefit stakeholders and thereby take positive actions to offset the crisis. Bolstering is a supplemental strategy to the other three. This posture includes the reminding, ingratiation, and victimizing strategies. Managers who have had positive relationships with stakeholders can draw upon that goodwill to help protect the organizational reputation, praise stakeholders for their efforts during the crisis as a means of improving relationships with them or draw sympathy from being a victim of the crisis.

The crisis response strategies described by Benoit (1995) and Coombs (2007a) present an extensive typology for understanding the initial post crisis response of an organization. Hence, the stream of crisis response models is utilized as the theoretical framework to interpret the communication strategies that HIH executives employed 
during their corporate collapse. In analyzing HIH's corporation communication during crisis, two research questions are guided in this study:

RQ 1) How did HIH manage their communication during the corporate crisis?

RQ 2) How were these communication strategies received and interpreted by the stakeholders?

\section{Method}

The current study is conducted using the case study approach. As a case analysis, this study is qualitative in nature. For the purpose of this study, the actions and communication strategies used by HIH are reviewed with information from its corporate website, press releases and media coverage. The organizational archival records, such as stock prices, sales and annual reports help explain the extent to which the crises have an impact on the stakeholders. In particular, the official government archival information, three volumes set of the HIH Royal Commission Report has added additional insight.

Media coverage was searched by the keyword "HIH collapse" in the two major Australian national newspapers: The Australian and The Australian Financial Review. Other international financial media reports, such as Business Week and the Wall Street Journal, were collected from the Nexis-Lexis Academic database. The selected news article data were used to explore how the major media told news stories about the crisis situation of HIH. Consequently, the contents of the collected news articles were qualitatively analyzed to find the major concepts embedded in the news coverage and the attitudes of news narration.

The analysis examined HIH's response to the crisis chronologically. The first time frame started in September, 2000, when the financial difficulties began in the market and ran through August, 2001. The analysis of the second time frame began with the post-collapse developments, such as the HIH Royal Commission Inquiry by Justice Neville Owen in 2003, and the sentencing to jail of the two HIH major directors, Ray Williams and Rodney Adler in 2005, through their release from prison in 2008.

The procedures for analysis involved three steps. First, after the data were collected from multiple sources, a detailed timeline of relevant events leading up to the crisis itself, and the post-crisis process was created. For example, the chronological order was constructed in the following manner: 1) financial difficulties in the market (September, 2000 - December, 2000); 2) provisional liquidation (February, 2001 - August, 2001); 3) verdict (March, 2002 - April, 2003); and 4) pleading guilty and sentencing (April, 2005). Second, after the chronological order of actual events were refined, a narrative description and process analysis of each event was thus constructed. A worksheet served as an organizing tool for evaluating each event. All data collected were analyzed using the typology of crisis response strategy. Finally, a detailed description and analysis of the findings of each research question was conducted.

\section{Analysis of HIH Crisis Response}

\subsection{Financial Difficulties in the Market}

Throughout HIH's steady demise during the final years, it failed to provide transparent information and disclosure of the extent of its deteriorating financial situation. In September 2000, HIH sold off half of its retail general insurance business to the German insurance giant, Allianz. HIH's price fell from A $\$ 1.05$ to A $\$ 0.45$ after an announcement of substantial losses and rumors within the financial community regarding the underlying financial condition of the company. In fact, three months earlier, steadfastly HIH denied it needed fresh capital to meet regulatory requirements for prudential margins established by the Australian Prudential Regulation Authority (Boreham, 2000). In June 2000, HIH made a statement that "based on our current three-year business plan and taking into account possible regulatory changes ... no capital raising is required, imminent or planned" (Boreham, 2000, p. 21). HIH continued in their denial by saying "the Australian market which accounted for $67 \%$ of total business remained a very solid core business base and the UK market which is HIH's largest international exposure will undergo a strong rate of recovery in the 2000-2001 year" (Boreham, 2000, p. 21).

HIH Insurance CEO Williams also wrote to the chief executives of all the major insurance brokers, assuring them that HIH was "rock solid" and paid "the vast majority of claims large and small, quickly" (Westfield, 2000a, p. 21). Williams further claimed that HIH was "sound and dependable," urging them to renew their clients' professional insurance needs with HIH (Westfield, 2000a, p. 21). Moreover, Williams asserted: "Our clear market leadership in professional indemnity and public and product liability as well as our innovation in workers compensation and other corporate classes provide tangible evidence of our expertise" (Westfield, 2000a, p. 21).

In the meantime, several other HIH directors purchased company shares in an attempt to give the impression that they were confident in the company's viability. The most significant purchases were made by Williams who 
acquired 1.7 million shares (Frith, 2001). Impatient shareholders who were watching their shares drop put pressure on Williams to raise money to rectify the problem. They also expected Williams to step down as CEO but Williams rebuffed any mention of calls for his resignation, even though the stock price continued to decline (Westfield, 2000b). Shortly after, HIH adopted a strategy of corrective action, announcing that the company had appointed a search firm to find a replacement. On October 12, 2000, shares in HIH soared nearly $21 \%$ when chief executive Williams announced he would leave the company by December. His resignation ended a 30-year association with the company he had founded (White, 2000). At that point, HIH employed a strategy of differentiation to put some distance between the company and Williams. In response to the resignation of Williams, Adler said "we are in a very vicious cycle and we need a circuit breaker and part of that circuit breaker will be unfortunately, Mr. Williams leaving and a new guy coming" ("Vicious cycle runs HIH down," 2000, p. 21).

After a brief search for a replacement, the board handed Williams's job to Randolph Wein, a Hong Kong branch director, although Williams continued to work as a consultant to the company. On December 15, 2000, Wein told the shareholders at the annual meeting that "I am convinced that an energetic and motivated management team will be able to restore the fortunes of the company and rebuild shareholders' wealth" (Westfield, 2001a, p. 29).

Simply put, HIH's message was designed to reduce the negative comments regarding the deteriorating financial condition and reassure the stakeholders that the company was on the path to recovery, which was further from the truth. HIH sought to conceal all the negative information about the financial status quo and sugar-coat the situation. Unfortunately, the misleading information eventually had a negative impact on the stakeholders.

\subsection{HIH in Provisional Liquidation}

HIH requested a suspension of trading its shares from February 22 to 25, 2001. In an effort to diminish the financial issues, HIH said it requested the suspension because a comprehensive statement on its finances would not be available until it had investigated the impact that its restructuring plan would have on the company. Market speculation put the loss at up to A $\$ 500$ million although $\mathrm{HIH}$ directors said they were "not at this point aware of the quantum of the interim loss" (Westfield \& White, 2001, p. 21). HIH affirmed that any estimates about the size of the loss were "pure speculation" (Westfield \& White, 2001, p. 21). Regulators and investors had become increasingly concerned that the company had not kept them fully informed about its affairs amid mounting speculation about the size of the expected loss (White, 2001a). As such, the Australian Securities \& Investments Commission (ASIC) forced HIH to suspend its shares for the second time and launched a formal investigation into the troubled company's market disclosure. The investigation focused on HIH's record of disclosure of price-sensitive information to the share market. The HIH spokesman said "we are continuing discussions with the ASIC and the Australian Stock Exchange ... to determine the limit to which we can go in providing information to the market that is reliable" (White, 2001a, p. 23).

On March 15, 2001, HIH was placed into provisional liquidation with losses of up to A $\$ 5.3$ billion. Tony McGrath said on the day he was appointed provisional liquidator, "it appeared to me that the HIH were all insolvent and that no recovery of the business ... was possible" (Dore, Harris, White, \& Magnusson, 2001a, p. 21). After the provisional liquidation, former CEO Williams kept a low public profile. Breaking months of silence, Williams defended his role in the demise of HIH Insurance and spoke of how the collapse of the company he founded 33 years ago had personally "devastated" him. Williams insisted he was unaware of the massive financial catastrophe facing the company, saying, "I was totally shocked, just shocked. If I didn't think the company was in solid shape I wouldn't have been saying what I did" (Magnusson, 2001a, p. 21). Although organizational leaders cannot know all that goes on in their organizations, they are responsible for maintaining a fundamental knowledge of operations and activities (Seeger \& Ulmer, 2003). As a CEO, Williams was fully involved in daily operations and decisions at $\mathrm{HIH}$. He appeared to seek conditions of plausible deniability in which he claimed his unawareness of some activities. According to Seeger and Ulmer (2003), such strategies are clearly unethical and designed to avoid accountability by manipulating his knowledge of the events.

Williams did not single out any one factor for the corporate disaster, instead pointing to a "whole series" of situations that caused the company to be put into provisional liquidation. Using the strategy of shifting the blame to others, Williams argued that "I was the CEO - that doesn't mean there weren't other executives that had autonomy over the way in which we operate," (Magnusson, 2001a, p. 21). Williams claimed he had not received a $\$ 5$ million severance package. Asked if he expected to see it, Williams said: "I hope so and I say that not for me personally. I hope the same for all creditors. I have suffered greatly financially by HIH going into voluntary liquidation," he added like a victim (Magnusson, 2001a, p. 21).

Again, Williams took a parting shot at his fellow directors on August 19, 2002, claiming they could have saved 
the company if they had not been trying to look out for their own interests. Williams said all directors were fully informed about HIH's finances and could have done more to save the company. He further shifted the blame and indicated that "perhaps it's wrong of me to say it, but I think instead of people trying to protect their backsides, really (trying) to protect this company and (going) to APRA I think the outcome would have been drastically different" (White, 2002, p. 3). Using the strategy of justification, Williams tried to justify himself by saying that "no one has put it to me that I was a crook. I may have made mistakes in my time. I may well have been a generous employer. I may have been taken in but I tried to act honorably" (White, 2002, p. 3).

With blame in the air, shareholders and directors questioned again whether the A $\$ 300$ million HIH had paid for FAI was too much. FAI was founded by Adler's father - a move contributed to the HIH collapse. The HIH Royal Commission (2003) pointed out that the takeover of FAI Insurances was "impetuous and based on completely inadequate information." As a result, Adler became the subject of an ASIC investigation relating to his role in the HIH collapse. By responding to this concern, Adler said that "FAI delivered to HIH some well-known brands, most of which had been sold into the Allianz joint venture, and that no one forced HIH to make the bid in the first place" (Westfield, 2000c). He further said that "I had a job to sell FAI and that's what I did. If they paid too much for it, then I did my job well" (Dore, Harris, White, \& Magnusson, 2001a, p. 21). In an effort to attack the accusers, he emphasized that it was management who were to blame for HIH's financial crisis, rather than the FAI acquisition. In particular, Adler distanced and excused himself from the disaster. He mentioned that he warned the board the company was facing financial problems more than six months before HIH went into provisional liquidation. He also sought to shift the blame through a scapegoat.

I don't want to single out Ray Williams, but as chief executive you take the credit and you take the blame. But the mistake wasn't Ray's alone. There was a team, an executive team, there was a board and ... everyone must take a percentage of blame. (Magnusson, 2001b, p. 4)

White (2001b) argues that "plenty of expressions of sympathy and regret have been made since the HIH collapse, but so far no one has said sorry" (p. 7). Williams cited legal advice in refusing to discuss the collapse. He only expressed "as a human being I want to put on record my sympathy and regret for what has happened" (White, 2001b, p. 7). As for Adler, he had hired a public relations consultant Anthony McClellan, a former 60 Minutes producer, to represent him. In a statement issued by McClellan, Adler claimed: "I was not involved in the day-to-day operation of HIH ... I was shocked when the extent of the losses became known. Also, I personally lost substantially through HIH" (Videnieks, 2001, p. 2). The statement said Adler was also upset "about the terrible fate that has befallen all those involved with $\mathrm{HIH}$ and that the interests of policyholders were paramount" (Videnieks, 2001, p. 2).

\subsection{Verdict}

Faced with criticism that Australia's watchdogs had failed to act on HIH's problems, the Australian Prime Minister John Howard quickly announced that a Royal Commission was established to investigate the company's collapse on May 21, 2001. Royal Commissions are special advisory and investigatory bodies rooted in Westminster-type democracies such as United Kingdom, Canada, New Zealand and Australia. The investigations of the Royal Commissions report directly to parliament. Royal Commissions are formally established in Australia by letters patent issued by the governor or governor-general on the advice of the government (Prasser, 2003). Letters patent appointing the HIH Royal Commission were signed on August 29, 2001 and Justice Neville John Owen was appointed to head the Commission.

The HIH Royal Commission mainly focused on several key issues such as: 1) when did HIH become unable to pay its debts on time, 2) whether the board or management withheld material information from shareholders, potential investors and APRA, 3) whether the board or management misled the market or APRA, and 4) the causes of the collapse, extent of the loss and those who are accountable. After sixteen months of commission hearings, the HIH Royal Commission's report was publicly released on April 16, 2003. In a 1500-page report, Justice Owen said he found no evidence of wholesale fraud or embezzlement behind the A\$5.3 billion collapse (The HIH Royal Commission Report, 2003). He pointed out that the failure was due to a lack of attention to detail, a lack of accountability for performance, and a lack of integrity in the company's internal processes and systems. The mismanagement and an inadequate response to emerging pressures in international insurance markets had caused the failure of HIH (The HIH Royal Commission Report, 2003).

In his report, Justice Owen particularly indicated a corporate culture in HIH that was characterized by blind faith in a leadership that was ill-equipped for the task. Directors of board were unduly deferential to Williams, who failed to challenge or endorse company strategy and had little understanding of conflicts of interest. By not coming to the realization of the serious problem of under-provisioning in the accounts, the board was never able 
to deal with the looming crisis (The HIH Royal Commission, 2003). Justice Owen stated the dominant personalities of Williams as follows:

No one rivaled him (Williams) in terms of authority or influence. Even as his business judgment faltered in the second half of the 1990s he remained unchallenged. No one else in senior management was equipped to grasp what was happening and to bring about a change of direction for the group. There was a lack of accountability among senior management and the board of directors, and there was a singular failure to assess performance in the context of deteriorating financial results. (The HIH Royal Commission, 2003)

In the end of the report, the HIH Royal Commission had cited 56 possible breaches of the Corporations Act or the Crimes Act, split equally between civil and criminal offences, and recommended that the Director of Public Prosecutions or the Australian Securities and Investments Commission considered laying charges. By responding to the HIH Royal Commission report, Williams argued Justice Owen had vindicated him. He claimed that the HIH Royal Commission treated him unfairly because his evidence was misquoted to other witnesses. Moreover, he denied any allegations and claimed that commission lawyers were focusing on irrelevant personal matters instead of investigating operations of the corporate collapse.

\subsection{Pleading Guilty and Sentencing}

On April 14, 2005, Adler, the former FAI managing director and HIH director was sentenced to four years and six months in jail, with a minimum of two years and six months after pleading guilty to four counts including lying about share purchases, obtaining money under false pretences and failing to discharge his duties as a company director (King, 2005). The first two charges dealt with purchases of HIH shares arose from an article in The Australian Financial Review on June 19, 2000 (Mellish, 2000). Adler told The Australian Financial Review journalist Morgan Mellish that he bought A $\$ 1.87$ million HIH shares with his own money and increased his stake to $1.6 \%$. In an attempt to stabilize and push up the HIH's declining share price, he mentioned that he was confident about the company medium-term outlook. However, the shares were bought through Pacific Eagles Equities which was funded by $\mathrm{HIH}$. He broke the law by lying about share purchases and obtaining money. Justice Dunford said that Adler had "disseminated information which he knew to be false, that he had purchased shares with his own money, which was likely to induce other persons to purchase HIH shares" (King, 2005, p. 4).

The third charge dealt with lies Adler told Williams in September 2000 about a planned A $\$ 5$ million fundraising for the company Business Thinking System. Adler was a director of the company, which was in financial straits. He asked Williams to invest A $\$ 2$ million because of A $\$ 2.5$ million shortfall. Adler said he would invest A $\$ 500,000$ but he had no intention at all. Judge John Dunford said that Adler had used his testimony to minimize his culpability in relation to a charge that he deceived Williams into believing he was investing $A \$ 500,000$ of his own money into a company.

In fact, Adler attempted to portray his deception as a thoughtless, unintended event. He told his sentencing hearing considering the charges of dishonesty and making intentionally misleading statements that saying sorry could not reverse the impact of his conduct. He told the New South Wales Supreme Court that, "There is no excuse. Even though I can justify it today, the justification is not acceptable. One would like to say sorry but there is no mechanism to say sorry. You can't reverse it" (Korporaal, 2005, p. 5). Further, he admitted telling lies to shareholders. He said,

I put my personal interest above the interest of $\mathrm{HIH}$... In a board sense; it was stupid errors of

judgment ... to cut corners in order to achieve a result. It was a serious error of judgment and not in the best interests of shareholders. (Sexton, 2005, P. 1)

Adler also portrayed himself as a victim and mentioned that he lost $\mathrm{A} \$ 10$ million in his investment in HIH shares after he sold them at a loss in September 2000. However, Justice Dunford was unconvinced by Adler's contrition and indicated his lies were deliberate. Justice Dunford said that "Although he accepts that his conduct is unacceptable to others, he does not really acknowledge to himself the full extent of its wrongfulness in the business sense" (Carson \& Warne-Smith, 2005, p. 1).

One day later, on April 15, 2005, Williams joined Adler behind bars. Williams was sentenced to four years and six months in jail, the same as Adler received, and a non-parole period of two years and nine months - three months longer than Adler. Williams had pleaded guilty to three charges arising from the management ineptitude of HIH between 1998 and 2000 (West, 2005). The first related to reckless conduct as a director of HIH when he signed a misleading letter. The second charge was related to the withholding of information from a prospectus, and the final, most serious charge, as Justice Wood described it was for the "financial reinsurance" breach. 
Subsequently, Justice Wood suggested that a proper standard of punishment was paramount.

On January 14, 2008, Williams walked out of jail. Finally, he offered his first apology. Williams told the reporters that "the last thing in the world I would have wanted was for HIH to fail, for people to be hurt and for people to suffer financial loss. And I really am very sorry that occurred" (Main, 2008, p. 3). Apparently, the apology was too late and was not much use to those HIH victims who lost their savings or their livelihoods. Main (2008) claimed that stakeholders believed that Williams's sentence was inadequate. According to Coombs (2007b), an unfavorable prior reputation will still intensify the reputational threat afterwards. Williams did not engage in a dialogue with their stakeholders and show little considerations for them during the crisis. He failed to take responsibility for the corporate collapse and assisted victims with concerns. Obviously, some stakeholders did not appear to forgive him. After his release from prison, the public resentment against Williams remained.

In short, the HIH collapse threw the insurance industry into chaos and left thousands of policy holders without cover. However, Williams and Adler either denied any wrongdoing or shifted the blame to each other. Table 1 shows the communication strategies HIH used from the period of the financial difficulties in the market to the sentencing of Williams and Adler.

Table 1. HIH's Communication Strategies

\begin{tabular}{|c|c|c|}
\hline Date & Events & Communication Strategies \\
\hline $6 / 2000$ & $\begin{array}{l}\text { Ray Williams writes to the chief brokers that } \mathrm{HIH} \text { is } \\
\text { rock solid, sound and dependable. }\end{array}$ & $\begin{array}{l}\text { Denial of speculation } \\
\text { about financial situation }\end{array}$ \\
\hline $9 / 2000$ & $\begin{array}{l}\text { HIH directors declare share purchases to show that they } \\
\text { have confidence in the company. }\end{array}$ & $\begin{array}{l}\text { Diminishing the financial } \\
\text { issue }\end{array}$ \\
\hline \multirow[t]{2}{*}{$10 / 12 / 2000$} & Ray Williams resigns as CEO. & - Differentiation \\
\hline & $\begin{array}{l}\text { Randolph Wein is appointed to the new position of } \\
\text { CEO. }\end{array}$ & - Corrective action \\
\hline $12 / 15 / 2000$ & Ray Williams resigns as director. & Corrective action \\
\hline $2 / 26 / 2001$ & Rodney Adler resigns as director. & Corrective action \\
\hline $2 / 22 / 2001$ & $\begin{array}{l}\text { HIH requests suspend trading of its shares from } \\
\text { February } 22 \text { to } 25,2001 \text {. }\end{array}$ & $\begin{array}{l}\text { Diminishing the financial } \\
\text { issue }\end{array}$ \\
\hline $2 / 27 / 2001$ & $\begin{array}{l}\text { Market speculation puts the HIH loss at up to } \mathrm{A} \$ 500 \\
\text { million. }\end{array}$ & Denial of speculation \\
\hline $5 / 18 / 2001$ & $\begin{array}{l}\text { Ray Williams hands in his passport and says he has } \\
\text { nothing to hide. }\end{array}$ & Denial of wrongdoing \\
\hline $5 / 12 / 2001$ & $\begin{array}{l}\text { Adler emphasizes management rather than the FAI } \\
\text { acquisition is to blame for HIH's crisis. }\end{array}$ & $\begin{array}{l}\text { - } \text { Shifting the blame } \\
\text { - } \text { Distancing \& Excuse } \\
\text { - } \quad \text { Scapegoating }\end{array}$ \\
\hline $6 / 8 / 2001$ & $\begin{array}{l}\text { Adler complains that he is a scapegoat and a victim of } \\
\text { the tall poppy syndrome. }\end{array}$ & Shifting the blame \\
\hline $8 / 19 / 2002$ & $\begin{array}{l}\text { Williams justifies himself by saying that he was but one } \\
\text { member of a 10-person board with one vote. Williams } \\
\text { uses FAI as the scapegoat for HIH's decline. }\end{array}$ & $\begin{array}{l}\text { - Shifting the blame } \\
\text { - Scapegoating }\end{array}$ \\
\hline $1 / 14 / 2008$ & $\begin{array}{l}\text { After serving four and a half years in prison, Williams } \\
\text { walks out of jail and offers his first apology. }\end{array}$ & Apology \\
\hline
\end{tabular}

\section{What Can be Learned?}

\subsection{Lessons on Ignoring the Warning Sign}

Arguably, HIH seemed to ignore the warning signs for its financial difficulties in the initial stage of the crisis. For example, a board member, Neville Head, sent a letter to the Chairman of the Board, raising concerns over the quality, amount and relevance of material provided to the board (Mellahi, 2005). He noted that the materials were insufficient to make decisions. Unfortunately, Head's concerns were ignored and marginalized by the CEO Williams and the Chairman Cohen. Head subsequently resigned from the company, in part due to the lack of response to his concerns. The HIH Royal Commission indicated that Head's concerns should not have been 
dismissed summarily. This was a lost opportunity for HIH because in June 1999, the company should have grasped the magnitude of a serious management problem (The HIH Royal Commission, 2003). Additionally, HIH employed six external actuaries. In 2000, the principal actuary, David Slee, warned that HIH was vulnerable and faced dire consequences unless it changed its accounting policies. Later, Slee warned the board again in March 2001: "It has become apparent that not all details have been supplied in a full and consistent manner in the past" (Dore et al., 2001b, p. 17). His warning appeared not to have reached the board or to have been ignored until the very end.

In fact, the inability to understand the warning signs prevented the board from taking early corrective actions, exercising proper oversight, and shouldering responsibility for the ethical missteps of their company. When the board finally did exercise some control over the company, the damage had already been done. Thus, Mellahi's claim that at the final crisis stage "the likelihood that board members can influence the board's decisions to any significant degree through the formal channel is minimal" proves true (Mellahi, 2005, p. 277).

While HIH had a corporate governance model -- clearly presented in their annual reports -- there was little, if any, evidence of the board periodically assessing the company's governance practices to ensure they were suited to the changing environment in which the company operated (The HIH Royal Commission, 2003). Boreham (2000) criticized HIH for not responding to what he called "a significant level of misinformation prevalent in relations to the company and its operation" (p. 21). If there had been a more prompt response to the problem, the situation at HIH might have been avoided.

\subsection{Lessons on Communication Responsibility}

Seeger and Hipfel (2007) state that the company has an interest in keeping its financial information confidential because of the effect this information can have on a company's marketplace standing. As a result, most of the companies consider that "corporate information is proprietary, private, and not subject to public disclosure" (Seeger \& Hipfel, 2007, p. 162). However, Belasen (2008) argues that "financial results should be communicated in a consistent, conclusive, and concise way and in a manner that shows the company is proactive and responsive" (p. 77). In accordance to standard financial accounting practices, publicly traded companies must provide updated financial information to the public. The stockholders have the right to know because the financial information is a key indicator of financial health of a publicly held company. In contrast, the Australian financial commentator, Mark Westfield (2001a), pointed out that the stock had been trading in an information vacuum for at least six months before HIH suspended the trading. Westfield (2001b) further captured the significance of HIH's mistakes,

HIH's main sin was its failure to publicly disclose its deteriorating position. Listed companies are obliged by law to warn the market of material information that might have an impact on their share price. HIH told the market the exact opposite, claiming as Williams did in a letter to insurance brokers last June that HIH was rock solid and here for the long-term. (Westfield, 2001d, p. 4)

Openness and transparency are essential conditions to ensure that stakeholders receive reliable information about the value of the company and their involvement and needs are being considered. Transparency is a necessary condition for financial success at the firm level (Bowie, 2004). As Fombrun and Rindova (2000) point out, "a primary mechanism for achieving transparency is expressive communication with stakeholders" (p. 94). Heise (1985) further indicates that transparent organizations "make available publicly all legally releasable information - whether positive or negative in nature - in a manner which is accurate, timely, balanced, and unequivocal" (p. 209). Transparency also implies openness, communication, and accountability. Openness in the financial reporting system is the fundamental requirement for the proper functioning of the system. This means that both the numbers and the statements made about them must be honest.

In the beginning, Williams said that he was devastated by the collapse, that he thought the company was in good shape and was unaware of the massive financial catastrophe facing the company. According to Seeger, Sellnow, and Ulmer (2003), denial is unlikely to be a successful strategy in cases where the crisis type indicates that the company is at fault. They indicate that "when the crises type suggests organizational culpability, denial will increase the harm by reducing credibility and creating the impression that something is being hidden" (p. 51). Coombs (1995) also argues that if the actions make an organization directly responsible for its impact, a strategy of distancing the organization from the crisis or a non-existence strategy that denies the existence of the crisis is thus futile. Too often, organizations are reluctant to respond due to fear of creating or enhancing legal liability (Seeger, Sellnow, \& Ulmer, 2003). In his rhetorical strategies, Williams rejected the claim in his denial, saying that the board was highly qualified and was made up of a majority of non-executive directors. He was only one member of a 10-person board with one vote. He never acknowledged that HIH did anything wrong and claimed 
that HIH was unable to raise additional money to cope with appalling market conditions. He denied that he had withheld information on HIH's losses from the board. Instead of taking responsibility for the decline and eventual liquidation of HIH, Williams said that "market conditions in the global insurance industry in the late 1990s were the worst in modern times. It, like a number of insurers in Australia and other insurers around the world, failed to survive that period" (Harris, 2003, p. 5).

Speaking of his charges, Adler complained that he was a scapegoat and a victim of the tall poppy syndrome (White \& Milligan, 2001). Adler claimed that he was a tall poppy paying a price for success. According to Haley (2007), a tall poppy is someone who stands above the crowd because of his achievements. It is the tendency of the media and the general public to use the tall poppy syndrome to belittle the achievements of prominent individuals. Specifically, the tall poppy syndrome is "the tendency to cut down the ostentatious or merely successful" (Haley, 2007, p. 34). Adler spoke of the shame that his criminal charges had brought on his family, but insisted there was no point in apologizing for his crimes against the shareholders of HIH (Korporaal, 2005). Moreover, direct confrontation strategies were frequently used by Williams and Adler while defending themselves and seeking scapegoats to evade responsibility for their misconduct. They were frequently criticized for lacking remorse, for failing to show contrition, and for failing to apologize and be seen to be apologetic for their role in the HIH debacle (West, 2005).

Belasen (2008) further points out that the lack of transparency creates asymmetry between communication activities and stockholders' knowledge about outcomes such as cash flows. When financial results are reported to a company's stockholders, this asymmetry is reduced. Company executives have more access to information than others because they are more likely to participate in the decision-making processes. Generally speaking, CEOs should often be the ones who communicate the company's condition and financial results to stakeholders. HIH did not reveal any negative information about their financial performance. The overstatement of HIH's profits was both misleading and significant. HIH even affirmed that any estimates about the size of the loss were "pure speculation" (Westfield \& White, 2001, p. 21). HIH founder and former CEO Williams provided a contemporary example of a corporate leader who violated the trust of the stakeholders.

\subsection{Lessons on Business Ethics}

HIH never voluntarily accepted responsibility for the decline and eventual liquidation of the company. The HIH Royal Commission attempted to identify those responsible for the misdeeds of many inept individuals. In the case of $\mathrm{HIH}$, there were four possible culprits: management, the board, the auditors, and some general regulators such as Australian Prudential Regulation Authority (APRA) and Australian Securities \& Investment Commission (ASIC). Subsequently, however, those named denied any wrongdoing. While the regulators and others accepted some of the blame, the primary responsibility for this debacle rested with the HIH management team starting at the top with CEO Williams (McLean, 2001).

Given executive misconduct in this case, the need for better business ethics seems obvious. Ethical issues are fundamental to organizations, to both their normal operations and to the abnormal conditions of a crisis (Seeger, 1997). HIH downplayed bad news, dissent, and warning signs. Moreover, Williams reduced communication with the board to overcome board opposition. Williams carefully managed the amount of time and nature of information given to the board members in order to control the board's decision-making process. Mellahi (2005) argues that Williams "made an example of dissenting board members, bypassing and marginalizing them, thereby setting into motion a destructive spiral of silence and self-censorship by the rest of members" (p. 275).

Business ethics in organizations also require value-based leadership that includes comprehensive standards of appropriate conduct, as well as openness to improve the organization's ethical performance. Organizations that ignore and violate stakeholder or fundamental social values, for example, are more likely to experience crisis (Seeger, Sellnow, \& Ulmer, 2003). The behaviors of Williams and Adler were judged as corporate misconduct because they were inconsistent with the values and norms of the business operations. In court, Justice Wood said Williams' behavior was "a most serious departure from the acceptable standards of competence and diligence expected of the chief executive officer of a major public company" (West, 2005, p. 33). Justice Dunford also commented that Adler's "offenses are serious and display an appalling lack of commercial morality" (Carson \& Warne-Smith, 2005, p. 1).

After the failure of HIH, Williams earned the title of Australia's most-hated man (Dalton \& Carson, 2005). In particular, he was severely criticized for his personal profligacy and wealthy lifestyle. Both Williams and Adler were members of the Order of Australia which is an order of chivalry established by Queen Elizabeth II, for the purpose of recognizing citizens for their achievement or meritorious service. After the criminal convictions, they were stripped of their Order of Australia medals. Williams was also banned by ASIC from managing an 
Australian corporation and acting as a director for ten years (O'Brien, 2008). For Adler, the ban was twenty years.

Ciulla (2004) argues that ethics lie at the heart of leadership. As Gini (2004) reminds us, the primary issue is not whether corporate executive will use power, but whether they will use it wisely. Therefore, there is a strong connection between successful leadership and ethical behavior. Communicating lies, or failing to answer reasonable questions when a leader is in the hot seat, is the foundation for a crisis (Barton, 2001). The values, the vision, and above all, the actions of the leader set the ethical tone and standards for the organization (Kanungo \& Mendonca, 1996). However, Williams and Adler put their own personal interests above loyalty to everyone else and the fate of the company. They wielded their individual power ruthlessly and abused the trust of those who worked for them. During the investigation, they attempted to portray themselves as "victims." The result was that they ended up becoming the "true villains" of the HIH collapse.

Williams and Adler were convicted of crimes related to their misconduct and dishonesty. Clearly, their sentencing indicated that unethical behavior by organizational leaders deserves harsh punishment. Their denial of wrongdoing, their shifting the blame to others and their refusal to take responsibility for their actions were not ethically sound. In fact, a crisis stemming from a scandal is difficult for a company to deny because the event is usually the result of fault, wrongdoing or misdeed. Research has shown that $95 \%$ of the people are more offended by a company's lack of honesty than by the crisis itself (Borda \& Mackey-Kallis, 2004). Ulmer, Sellnow, and Seeger (2007) conclude that regardless of how the crisis is approached, leaders should be visible, open, and honest. Simply put, in any crisis, whatever the extent of the damage, a truly authentic leader is able to communicate the realities and possibilities in a context of complete, unwavering honesty (Schoenberg, 2005).

\section{Conclusion}

The HIH case demonstrates what can happen when corporate executives put their personal interests above the company's interest and the board of directors fails to live up to its responsibilities. Moreover, it delineates the importance of transparency and open communication. Denial and shifting the blame to others were the prototypical strategies of HIH's corporate executives as they tried to distance themselves from the wrongdoings. HIH denied that the company had financial problems and refuted speculation from the media. As the bad news spread, the finger-pointing and public fights between Williams and Adler began and continued unabated. After the collapse of $\mathrm{HIH}$, Williams shifted the blame further by saying that he was only one member of a 10-person board and tried to distance himself from responsibility for the corporate failure. As for Adler, he portrayed himself as a victim of the "tall poppy syndrome" and mentioned that he also lost substantially in his investment in HIH shares. The jail terms of Williams and Adler were further demonstration that the Australian legal systems had reformed and hardened their approach to wrongdoing by company directors. Justice Owen commented that this debacle should serve as a reminder to all shareholders that they need to be especially alert to a firm's corporate governance (The HIH Royal Commission, 2003).

Pauchant and Mitroff (1992) indicate that those organizations, which ignore messages signaling problems, are more prone to experience crises. Clearly, the inability to handle warning signals also indicates a potential threat to the organization's future survival. They also indicate that crisis-prone organizations are those managed by individuals who fail to take responsibility. Furthermore, they suggest that managers need to engage stakeholders in dialogue regarding key ethical issues. In the case of $\mathrm{HIH}$, corporate executives were not aware of or ignored their potential unethical practices and eventually created a crisis for their organization. HIH also created impediments to the communication of crisis signals. If HIH had protocols and mechanisms in place to manage issues in a timely or responsible manner when they emerged, these crises may have been avoided or the magnitude of the crises have been minimized (Coombs, 2007a).

More (1995) claims that only about one-third of Australian organizations have some type of crisis management planning in place. She argues that Australian organizations not only do not prepare for the dysfunctional dimensions of crisis, but they also are not aware of the positive dimensions or the real role that crises per se play in organizational life. Admittedly, the debacle of HIH demonstrated the need for good corporate citizenship and corporate social responsibility. The failure of $\mathrm{HIH}$ had led to intensive investigations of reporting practices and proposals for change with the intention of giving shareholders greater confidence in a company and their investments. In the past, white-collar crimes tended to be seen as victimless crimes. The Australian government has now introduced some reforms for protecting corporate whistle-blowers and tightening audit practices, including a mandatory audit committee to be established for Australia's top 500 corporations (Frith, 2005). The corporate regulator ASIC, is much more vigorous today in pursuing corporate crimes.

In brief, an organizational dilemma can test how companies treat corporate social responsibility, which can lead 
to failures of openness and transparency and result in a crisis. Corporate executives need to identify and examine what they regard as the basic moral underpinning of their system of values in order to safeguard their reputation and credibility.

\section{References}

Barton, L. (2001). Crisis in organization II. Cincinnati, OH: South-Western.

Belasen, A. T. (2008). The theory and practice of corporate communication. Thousand Oaks, CA: Sage Publications.

Benoit, W. L. (1995). Accounts, excuses, and apologies: A theory of image restoration strategies. Albany: State University of New York Press.

Borda, J. L., \& Mackey-Kallis, S. (2004). A model for crisis management. In D. P. Millar \& R. L. Heath (Eds.), Responding to crisis: A rhetorical approach to crisis communication (pp. 117-138). Mahwah, NJ: Lawrence Erlbaum Associates, Inc.

Boreham, T. (2000, June 16). Rest insured, capital rules OK. The Australian, p. 21.

Bowie, N. E. (2004). Why conflicts of interest and abuse of information asymmetry are keys to lack of integrity and what should be done about it. In G. G. Brenkert (Ed.), Corporate integrity \& accountability (pp. 59-71). Thousand Oaks, CA: Sage Publications.

Carson, V., \& Warne-Smith, D. (2005, April 15). Caviar days over of the next 21/2 years as Adler found to have deluded even himself. The Australian, p. 1.

Ciulla, J. B. (2004). Ethics: The heart of leadership (2nd ed.). Westport, CT: Praeger.

Coombs, W. T. (1995). Choosing the right words: The development of guidelines for the selection of the appropriate crisis-response strategies. Management Communication Quarterly, 8(4), 447-476. http://dx.doi.org/10.1177/0893318995008004003

Coombs, W. T. (2007a). Ongoing crisis communication: Planning, managing, and responding (2nd ed.). Thousand Oaks, CA: Sage Publications.

Coombs, W. T. (2007b). Protecting organization reputation during a crisis: The development and application of situational crisis communication theory. Corporate Reputation Review, 10(3), 163-176. http://dx.doi.org/10.1057/palgrave.crr.1550049

Cotterrell, R. (2000). Transparency, mass media, ideology and community. Cultural Values, 3, 414-426. http://dx.doi.org/10.1080/14797589909367176

Dalton, R., \& Carson, V. (2005, April 16). No claim bonus: Williams's discount on jail time. The Australian, p. 1.

Dore, C., Harris, T., White, A., \& Magnusson, S. (2001a, May 12). Big win on the eve of destruction? The Australian, p. 21.

Dore, C., Harris, T., White, A., \& Magnusson, S. (2001b, May 12). Who's to blame? The Australian, p. 17.

Duarte, F., McAllister, G., \& Gray, J. (2005). Spivs, shonks and ruthless sharks: Using discourse analysis to investigate identity construction in the HIH narrative. Retrieved from: http://www.mngt.waikato.ac.nz/ejrot/cmsconference/2005/proceedings/talkandtext/Duarte.pdf (October 2, 2011)

Fombrun, C. J., \& Rindova, V. P. (2000). The road to transparency: Reputation management at Royal Dutch/Shell. In M. Schultz, M. J. Hatch, \& M. H. Larsen (Eds.), The expressive organization (pp. 77-96). Oxford University Press.

Frith, B. (2001, May 16). HIH shareholders threaten to start class action. The Australian, p. 22.

Frith, B. (2005, April 16). Corporate crimes have to account. The Australian, p. 36.

Gini, A. (2004). Moral leadership and business ethics. In J. B. Ciulla (ed.), Ethics: The heart of leadership (pp. 25-44). Westport, CT: Praeger.

Grunig, J. E. (2001). Two-way symmetrical public relations: Past, present and future. In R. L. Heath (Ed.), Handbook of Public Relations (pp. 11-30). Thousand Oaks, CA: Sage Publications.

Haley, F. (2007). Check mate: In Australia, the proudest man in the patch gets mowed down. Psychology Today, 40(3), 34-35.

Retrieved from: http://www.psychologytoday.com/articles/200705/global-psyche-aussie-check-mate (December 1, 2011) 
Harris, T. (2003, January 25). My gold taps irrelevant. The Australian, p. 5.

Heise, J. A. (1985). Toward closing the confidence gap: An alternative approach to communication between public and government. Public Affairs Quarterly, 9(2), 196-217. http://www.jstor.org/stable/40861057

Kanungo, R. N., \& Mendonca, M.(1996). Ethical dimensions of leadership. Thousand Oaks:CA Sage Publications.

King, D. (2005, April 15). Lies and deceit come back to bite him. The Australian, p. 4.

Korporaal, G. (2005, March 31). Sorry's the hardest word for Adler. The Australian, p. 5.

Magnusson, S. (2001a, April 6). HIH founder “devastated.” The Australian, p. 21.

Magnusson, S. (2001b, May 17). I warned six months before crash. The Australian, p. 4.

Main, A. (2008, January, 15). Sorry says HIH founder as he's let out of jail. The Australian, p. 3.

McLean, T. (2001, March 20). Regulators failed in fall of HIH. The Australian, p. 30.

Mellahi, K. (2005). The dynamics of boards of directors in failing organizations. Long Range Planning, 38, 261-279. http://dx.doi.org/10.1016/j.lrp.2005.04.001

Mellish, M. (2000, June 20). HIH director goes on buying spree. The Australian Financial Review, p. 29.

More, E. (1995). Crisis management and communication in Australian organizations. Australian Journal of Communication, 22(1), 31-47.

O'Brien, N. (2008, January 14). Williams walks free today but HIH victims continue to pay the penalty. The Australian, p. 5.

Pauchant, T. C., \& Mitroff, I. I. (1992). Transforming the crisis-prone organization. San Francisco: Jossey-Bass.

Pearson, R. (1989). Business ethics as communication ethics: Public relations practice and the idea of dialogue. In C. H. Botan \& V. Hazleton Jr. (Eds.), Public Relations Theory (pp. 111-131). Hillsdale: NJ: Lawrence Erlbaum Associates.

Prasser, G. S. (2003). A study of Commonwealth public inquiries. Unpublished doctoral dissertation, Griffith University, Queensland, Australia. Retrieved from http://www4.gu.edu.au:8080/adt-root/uploads/approved/adt-QGU20060811.160901/public/02Whole.pdf

Schoenberg, A. (2005). Do crisis plans matter? A new perspective on leading during a crisis. Public Relations Quarterly, 50, 2-7. $\quad$ Retrieved from http://www.webpages.uidaho.edu/css594/secure/lessons/05/schoenberg\%20crisis\%20plann\%20leadrshp.pdf

Seeger, M. W. (1997). Ethics and organizational communication. Cresskill, NJ: Hampton Press.

Seeger, M. W., \& Hipfel, S. J. (2007). Legal versus ethical arguments: Contexts for corporate social responsibility. In S. K. May, G. Cheney, \& J. Roper (Eds.), The Debate over Corporate Social Responsibility, (pp. 155-166). New York: Oxford University Press.

Seeger, M. W., Sellnow, T. L., \& Ulmer, R. R. (2003). Communication and organizational crisis. Westport, CT: Praeger.

Seeger, M. W., \& Ulmer, R. R. (2003). Explaining Enron: Communication and responsible leadership. Management Communication Quarterly, 17(1), 58-84. http://dx.doi.org/10.1177/0893318903253436

Senge, P. M. (1990). The fifth discipline: The art and practice of the learning organization. New York: Doubleday.

Sexton, J. (2005, March 30). Adler admits stupid lies. The Australian, p. 1.

The HIH Royal Commission. (2003). Report of the HIH Royal Commission. Retrieved from http://www.hihroyalcom.gov.au/ (October 2, 2011)

Thomsen, S. R., \& Rawson, B. (1998). Purifying a tainted corporate image: Odwalla's response to an e. coli poisoning. Public Relations Quarterly, 43(3), 35-46.

Ulmer, R. R., Sellnow, T. L., \& Seeger, M. W. (2007). Effective crisis communication: Moving from crisis to opportunity. Thousand Oaks, CA: Sage Publications.

Van Riel, C. B. M. (1995). Principles of corporate communication. London: Prentice Hall.

Vicious cycle runs HIH down. (2000, October 31). The Australian, p. 21. 
Videnieks, M. (20001, June 1). Spin doctor on the job. The Australian, p. 2.

West, M. (2005, April 16). Nobody loves Raymond. The Australian, p. 33.

Westfield, M. (2000a, July 18). HIH hype can't hide grim reality: Future of HIH is too grim to ignore. The Australian, p. 21.

Westfield, M. (2000b, August 22). Friendless HIH between a rock and a vicious circle. The Australian, p. 21.

Westfield, M. (2000c, October 5). Adler's HIH loss-sell a sure sign that Williams must go. The Australian, p. 17.

Westfield, M. (2001a, February 28). ASIC delves into HIH's cloak and dagger dealings. The Australian, p. 21.

Westfield, M. (2001b, June 19) Howard wants truth to take time: HIH Royal Commission. The Australian, p. 4.

Westfield, M., \& White, A. (2001, February 27). Punters see red at HIH. The Australian, p. 21.

White, A. (2000, October 13). HIH on rise as Williams bows out. The Australian, p. 25.

White, A. (2001a, February 28). HIH told to show and tell. The Australian, p. 23.

White, A. (2001b, May 19). Sympathy, regret but no sorry. The Australian, p. 7.

White, A. (2002, August 20). Williams attacks HIH board. The Australian, p. 3.

White, A., \& Milligan, L. (2001, June 8). I'm a tall poppy paying price for success. The Australian, p. 4. 